Use of $L i(d, n)$ Neutrons for Simulation of

\title{
Radiation Effects In Fusion Reactors
}

By acceptonce of this article, the publisher and/or recipient acknowledges the U.S. Government's right to refain o nonexclusive, royalty-free license in and to ony copyright covering this puper. 
1975 Part. Accel. Conf., Washtngton, D.C. March 12-14, 1975

USE OF Li(d,n) NEUTRONS FOR STMULATIC" OF RADLATION EFFECTS IN FUSTON REACTORS."

A. N. Goland and C. L. Snead, Jr.

Brookheven Nationel Leboratory

Upton. New York 11973

D. M. Parkin

Los Alanow Sclearif 1c Laboratory

Lo Alasos, Naw Mexico 87544

and

R. B. Theun

Naval Research Leboratory

Gashington, D. C. 20320

\section{Surnery}

In th1 paper we thow that the neutron apectrum fron high-eneray deuteron boubardwent of * th1ck L1 target is uitable for imulation of radiation effecte In a fueion reactor. Neutron spectra fros 15, 20, 25, 30 and 35-4ay deuterons incident, reapectjvely, on a 2-ce thick 11 tarset are reported. For these spectra, a recently-developed conputer code was used to evaluace demge-energy cross sectione, primary recoll energy diotributions, and apectructaveraged reaction crose sectione in everal metale. The results indicate that a $(d, n)$ source can almulate the energy dependence of the recoll spectrs, and the rate of hellum production anticipated in a real funion renctor

\section{Introduction}

Intense neutron sources are required for in eltu measurements of physical property changes, tranalent radiation effects, and neutron dose-rate dependences and for blanket studies owociated with fubicn reactora. I large-voluae experiments must be conducted with anplea at high or lor tenperature over long perlode of tive at fluxe exceeding $10^{14} \mathrm{n} \mathrm{cm}^{-2} \mathrm{aec}^{-1}$. In any casea $1 t$ w111 be dealrable to alter the noutron epectrum to oimulate that anticipated at different positione in a hypothetical fusion reactor. All of thene conalderations lead us to the concluaicn that an accelerator-baed source 10 the most veratile one attainable in the next decade.

Frow the viewpolnt of CTR radiation-ef fecte stud1 os the usefulness of this aource depends upon positive answers to two queations. Firat, can a neutron nource of high flux in an edequate volune be produced? Second. with reopect to radiation damage, can the neutron apectrum of the source be used to simulate effecte that ane anticipated in a typical fualon reactor? These two anpecte of the Broukhaven Intense neutron source baed on a high-current deuteron LIMAC are under invearigation. To explore the firat queation, we have neanured the thick-target neutron apectra and yfelds from the $L 1(d, n)$ reactions as a function of incldeat deuteron energy. In order to Investigate the second queation, we are uning a program developed at Brookhaven to compare the radiation-damage effectivaness of diverse neutron sources.

\section{L1 $(d, \Omega)$ Spectrum Mep uremente}

Uaing the neutron time-of-f11ght spectrometer at the Naval Retearch Laboratory Cyclotron, we have obtained neutron apectra from the $(d, n)$ reactions in a thick lithium target. Data were obtalned for five

"Regearch sufported by the Bnergy Research and Development Adminiotration. deutron energiea, nominally 14.5, 20,25, 30 and $35 \mathrm{MeV}$. The energy of the deuterone incident on the Li target wa epproximately $0.5-1 \mathrm{MeV}$ lower in eacts sase because the deuter on beam passed through $0.005 \mathrm{~cm}$ of aluminum and $7.5 \mathrm{~cm}$ of air before entering the target.

At 13.42 and $34.06 \mathrm{MeV}$, angular-diatribution data were taken for angles of $0^{\circ}, 5^{\circ}, 10^{\circ}, 15^{\circ}$ ad $20^{\circ}$. In addition, Be $(d, n)$ data were obtalned for conparison with ariler NRI renulta taken when the Be target was inolde the cyclotron vacuum chamer. These data establiehed that the effect of using the target in alr - rather then in vacuum was negilgible.

The data were collected in - multiparameter mode and were reduced to obgolute yielis in units of neutrons/ar-C-HeV as a function of neutron energy. The neutron spectra then werved a input to the BNL code wh1ch generates those radiation-dange parameters neccasary for the evaluation of neutron source an imulatora of CTR neutron darage.

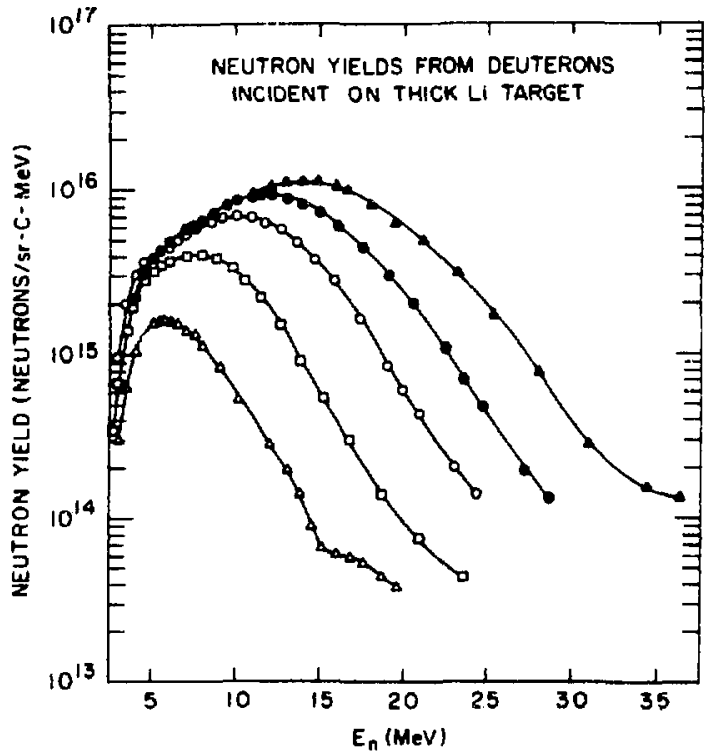

F18. 1 Neutron Spectra from 13.42-, 18.95-, 24.84-, 28.94-, and 34.06-HeV Deuterons Inc1deut on Thick L1 Target. 
IIgure I showe the neutron spectra for the five energles mentloned earlier. The meon energy Incressed with deuteron energy and 1a approxinately equal to $0.5 E$ (deut). The yield alwo lacreased with increang energy.

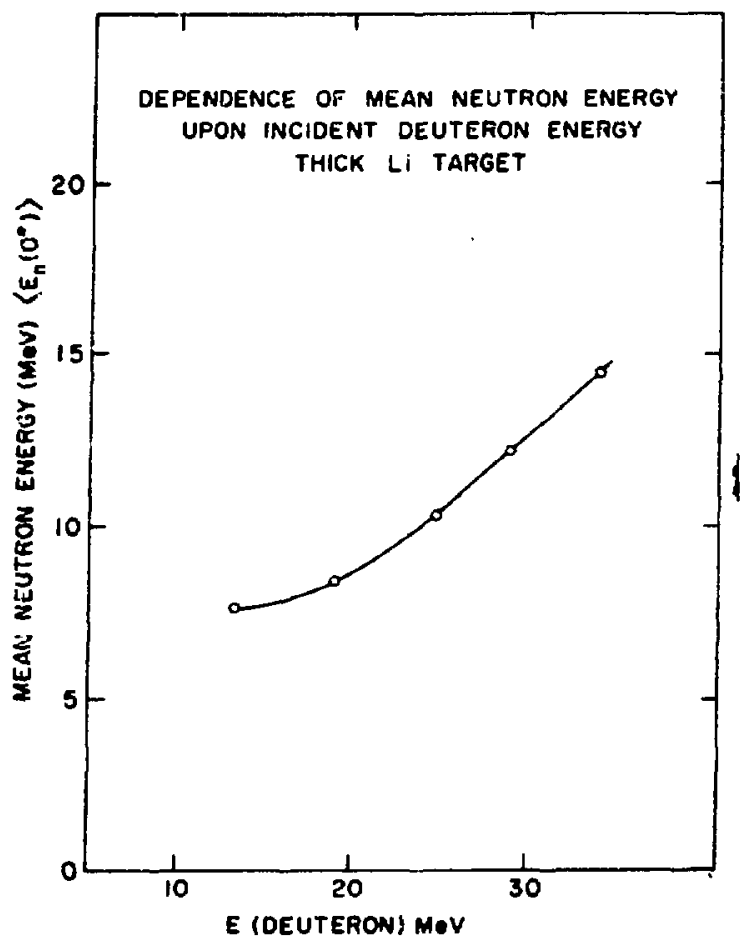

F18. 2 Dependence of kaan Meutron Energ Upon Incident Deuteron Enercy.

Figure 2 exhlbite gxaphically the dependence of the man neutron anercy at $0^{\circ},\left\langle E_{(}\left(0^{\circ}\right)\right\rangle$, upon the Incldeat deuteron energy. The figule how that $\left\langle E_{p}\right\rangle$ 11 se between 0.4 and 0.55 tIees the Incident deuteron enersy, approsching the lower value so the deuteron energy 1ncreanes. Tor - given energy $\left\langle\mathrm{E}_{n}\right\rangle$ varlea only -lightly an the acattering angle 1ncreanea, wherena the yleld decreane with increaning acatterins ansle. The reaulte conf1re the fact that the forwerd direction 10 atrongly favored in the $(d, n)$ reactions. The yield at $10^{\circ}$, for exaple, 10 elightly more than onehalf that et $0^{\circ}$ for 34.06-keV Incident deuterone.

Table I contalns values of the medoured yleld at $0^{*}$ In neuirona/nr-C for all secouresente ande. More precine velues could be obtalned by extrapolating the Deatured neutron epectre to sero deuteron energy. In gegeral, this would lacrease the ylelds by lene than 5 pereent. Wo have onlted thie uncertain extrapolnthon and, therafore, our aubaequent flux entratas any be regarded a belng conanrvatlve. Our aeaurad ylelde are ualforaly lover than those publiahed by Weaver, et al. " for deuteron energles up to $19 \mathrm{MeV}$ or those bared upon a llnaer extrapoletion of their data to 35 kaV. At preaent we do not fully undaretand why the diacrepancy existe, but 1 t 1 oost likaly attributable to an error in benor-current meanurement during one or both of the experiments, a difference 1n colilnation, and differeaces in the extrapolation to zero of the neutron energy.

\begin{tabular}{|c|c|c|c|c|c|c|}
\hline $\begin{array}{l}\text { E (deut) } \\
\text { (MeV) }\end{array}$ & $\begin{array}{c}\left|E_{1}\left(0^{\prime}\right)\right| \\
(\mathrm{MeV})\end{array}$ & $Y\left(O^{*}\right)$ & $Y\left(3^{\circ}\right)$ & $y\left(10^{\circ}\right)$ & $\gamma\left(15^{\circ}\right)$ & $Y_{1}\left(20^{\circ}\right)$ \\
\hline 13.42 & 263 & $9.605 \times 10^{10}$ & $9419 \times 10^{10}$ & $7.810 \times 10^{13}$ & $6339 \times 10^{13}$ & $1992 \times 10^{13}$ \\
\hline 18.95 & 8.46 & $3.247 \times 10^{10}$ & & & . & \\
\hline 2489 & 10.32 & $2129 \times 10^{10}$ & . & & & \\
\hline 28.94 & 12.21 & $1037 \times 10^{19}$ & - & - & . & \\
\hline 34.06 & 14.46 & $1469 \times 10^{14}$ & $1313 \times 10^{14}$ & $0.8697 \times 10^{14}$ & $09904 \times 10^{17}$ & $04160 \times 1014$ \\
\hline
\end{tabular}

\section{Comparieon with other celculat lone}

Several yeare ago ve began to develop a code for evaluating radiation-dange parageters anociated with various neutron cources. The code 10 comblaction of exiet Ins work by Jenkinas and by Doran, 6 extended to laclude calculations of apectrub-averaged croes sect1one and recoli-energy diatributiona. Deta1ls are givan In a recent Brookhaven report. ${ }^{3}$ The philosophy which we have adopted is that ve with to calculate radiation-dange parameter which are codel independont. Thene wy be uned vith a variety of models to ake comperisone with experimental results. It is poaslble that. different adel w111 be needed for each kind of experierent.

-

Rulcinak1, Doran, and Abdou' have generally included a aple model of diaplacenent production in thelr calculation. 00 that they can quote dieplacesents par aton (dpa) per un1t tise. They also quote tranobutation product production ratas werean we 1lat spectru-dvereged crose sectlons. A comparioon between the1r approach and ours lilustrates the connection:

Kulc1nski, el el. calculate the total displacement cro.:- aection at energy $E$ :

$$
F(E)=\int_{E_{0}}^{T_{\max }} \sigma(E) p(E, T) \cup(T) d T
$$

where $\sigma(E)$ 1s the appropriate Interaction cross sec$t 10 n, P(E, T)$ 1s the probability that a peutron of energy E tranafers energy $T$ to a recoll atom, $U(T)$ is the number of diaplecenente produced by a recoll atom of energy $T$ (a model-dependent quantity), and $E_{0}$ 1s the antaue energy required to diaplace in atos. 
BLon:

Parkin and colend calculate the equivelent expres-

$$
G(E)=\int \sigma(E) R(E, T) g(T) d T
$$

there $\sigma(B)$ has the ane maning co above, $K(E, T)$ correnponds to $\mathrm{p}(\mathrm{I}, \mathrm{T})$, and $\mathrm{g}(\mathrm{T})$ 10 a core generel fore of $v(\tau)$.

In order to salculate the diaplecenent crose sect1on Kulc1ank1. at ol. set $V(T)-\left(B / 2 E_{0}\right)[L(E) / \varepsilon] T$. where Bro. B, and $L(E) / E$ te the fraction of racoll eneres which io avaliable to caune displecenota. The fector $B / 2 E_{0}$ 1. baend upon a olmple dieplecerent model Introduced by Rinchla and Peuse and recently 1mproved by robinton and Torrens." It cannot take 1nto accoumt the apatial dietribution of the diaplacenate or the1r cluater are distribution.

Parkin and Goland ube the correnpondins quantity: $g(T)=T(T)=T[L(\epsilon) / \varepsilon]$ to celculate the dangeener 8 croce eection, $\mathrm{E}_{\mathrm{D}}$. Thus In this case the correopondonce 1s:

$$
v(T)-\left(B / 2 E_{\alpha}\right)(T) \text {, and } P(E)-\left(B / 2 E_{\alpha} \psi_{T}(E)\right. \text {. }
$$

Finally, the Brookheven calculatione are evaraged over flux dietribution: thich have been noreallzed to one neutron $\mathrm{cm}^{-2}$ eec $^{-1}$. Therefore,

\begin{tabular}{|c|c|c|c|c|c|c|}
\hline \multicolumn{2}{|c|}{ Table II } & \multicolumn{4}{|c|}{ 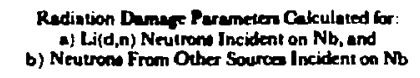 } & \multirow[b]{2}{*}{$\begin{array}{c}\left(E_{0}\right) /\left(O_{T}\right) \\
(e V)\end{array}$} \\
\hline (A) & $\begin{array}{l}\text { Extem } \\
\text { (MeV) }\end{array}$ & (aber) & $\begin{array}{c}\text { (onew) } \\
\text { barn }\end{array}$ & $\underset{\text { bartiev }}{\left|E_{D}\right|}$ & $\begin{array}{c}\left(E_{D}\right\} /\left(0_{0 . a}\right) \\
(\mathrm{eV})\end{array}$ & \\
\hline & 13.42 & $2.269 \times 10^{-1}$ & 3.972 & $1.230 \times 10^{4}$ & $7.624 \times 10^{7}$ & $4.553 \times 10^{0}$ \\
\hline & 18.95 & 3.245 & 3.907 & 1.899 & 3.832 & +763 \\
\hline & 24.81 & 4.834 & 3.803 & 2126 & 4390 & 5590 \\
\hline & 28.94 & 6.001 & 3.349 & 2.315 & 3.858 & 6.523 \\
\hline & 94.06 & 6.949 & 3221 & 2.331 & 3.642 & 7.858 \\
\hline \multirow[t]{6}{*}{ (b) } & Source & & & & & \\
\hline & $\overline{\text { HFTR }}$ & $1 \times 10^{-3}$ & 6.006 & $2.24 \times 10^{4}$ & $2.24 \times 10^{0}$ & $3.730 \times 10^{3}$ \\
\hline & EDRII.7 & $6 \times 10^{-6}$ & 6.354 & $2.8 \times 100$ & $4.67 \times 10^{0}$ & $4.407 \times 10^{9}$ \\
\hline & LAMPF & $4 \times 10^{-4}$ & 6.614 & $5.6 \times 10^{5}$ & $1.40 \times 100$ & $0.467 \times 10^{9}$ \\
\hline & DENCH & $2 \times 10^{-3}$ & 5.718 & $9.52 \times 10^{4}$ & $4.76 \times 10^{7}$ & $1.665 \times 10^{4}$ \\
\hline & "14 MeV" & $=3 \times 10^{-9}$ & 3.965 & $2.74 \times 100$ & $3.046 \times 10^{9}$ & $6.910 \times 100$ \\
\hline
\end{tabular}

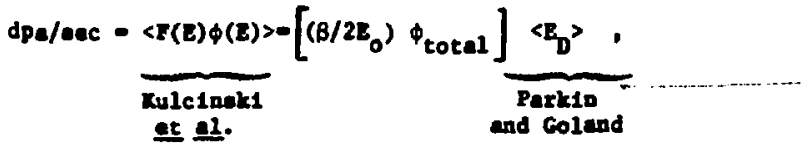

where the asbol < > denotes a opectral average.

\section{Renulte}

The neutron opectre obtalned in the $(d, n)$ experiente were put on a comon 47-polat eners srld by eane of linear laterpolation betrean the ortiglnal dace polate. Values of the specter for low-enery neutrone wera obtalned by linear extrapolation to E=0 from che lowset enorgy menured. Th1e lest approxinetion 1s not vary sood, but the lov-anersy neutrone coatribute to licele to the 1mportent rediatioa-danage perasetere that a better appioxination vas not ough:

Exaples of the Brookhaven reaulte for th given relative to unit flux are listed In Table II-a for the I1 $(d, a)$ Easuranents, and In Table II-b for other coursea. It 1t difficult to find eccepteble values for total fluxes in other sources, but for the fluxes lieted In Table III, the number of dpoive and the rote of Induced ses production in $\mathrm{Bb}$ ore efiven in absolute unite.

The raeulte of the celculatione for aloblu 1aclude the nornallzed prieary recoll enercy opectrib, varlous epectrun-aversed crose sectlow weh os $\left\langle a_{n, a}\right\rangle$, and the darage enarev crose eaction, $\left\langle E_{D}\right\rangle$. Ae enticipated, the recoll opectrue thifte to higher enersy a the deuteron mergy Increenee. The opectrua-avereged dange anersy croes eection and the opectru-overeged $(n, a)$ croes eection also increnes vith iacreaslns deuteron caersy. However, thile $\left\langle\sigma_{n, a}>\right.$ Increases by a foctor of three between 13.42 and $34.06 \mathrm{keV},\left\langle E_{\mathrm{D}}\right\rangle$ only 1acreesee by about 46 percent. Tabie II-a contelne veluee of theee qunntities for the varloue $(d, n)$ neutron epectra. Noo 110ted ore the ratio of avereged dange enersy crose enction to $(a, a)$ crose sect1on, $\left\langle b_{b}\right\rangle /\left\langle a_{n_{2}} a\right\rangle$, and the damse enercy per priery reco11, $\left.\left\langle E_{D}\right\rangle /<a_{\text {Totel }}\right\rangle$. Theee two quentitioe ere eapecielly ueaful for comprison with other extetios or proposed atmulation or 14-lieV neutron nources. In fact, Tabls II-t stvas values of tha can parameter as Table II-a for sevaral othar seutron sources. Spectru-averaged quantitese vero calculatad for unit nutron flux.

A cosparioon of Toble II-a and II-b is very reveeling. The entry lobeled BENCH in Table II-b represente the f1rat-wall neutzos opectrua calculated on the beate of - ecanderd blanket dec1 $\mathrm{mo}$. ${ }^{10}$ If we adopt thie opectru as our reference, than we cen draw the following concluolons concernins $(d, n)$ neutrone for the deuteron onerby range under conolderet1on.

1. The value of $\left\langle\sigma_{n}, a^{\rangle}\right.$exceede the BZHCH velue by at wot a factor of 3 then ib 10 aposed to $(d, n)$ neutrone. Other eourcee fall to produce en equivelent anount of hellue by oxders of megritude except in the case of 4 14-inv source for which $\left\langle\sigma_{n, a}\right\rangle$ is lereer by - factor of 4,S.

2. The $(d, a)$ cource lesde to darage-energy sooe

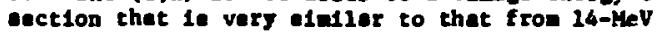
aeutrons. Both sourcas exeed the BATCH value by bout - factor of two, the 14-Miv velue differins sowmbt wore than the $(d, n)$ values.

3. The rat10 of deage-enercy croes eaction to $(n, a)$ crose eection can be regarded as asesure of the ab111ty of a eource to almulete the elmultaneous ganerecion of defecte and heliue. For the $(d, n)$ source, this ratio alwaye differe by lese than a factor of two from the Bxch yelue For the oppropripte deuteron eperty, ${ }^{2} 23$ mo the ratio can be 
On the baste of this analyols, it appears that a 15-30-MeV deuteron LINAC would eatiefy the requirewate of a CTR neutron eleulation cource. The man enargs of the neutrone could approxituate that of a Bexichine apectur or could be alterad to more clonely metch that of other aources. As the yleld increaseg vth Increasing energy the beet cholce of energy for a long-tere experdent will depend upon the ultiante douteron current ava1lable. Th1 in eura will be deternsiond by mource and target developmente in the aexe fer yenre. If very h1gh current sources cen be maddad to the LIMnc, end if the bean power can be handled In the L1 terget, then the lower deuteron energles ay be oelectad without oacrificing too much aoutron flux. At present th1 approech seen to yleld the beet egreament whth the andain ausber of radiatlon-danege parantere.

\section{Beferepcea}

1. Tueton Reactor Firat Wall rinteriala, l. C. Inaniello, ed., U.S.A.E.C. Report, WhSH 1206 1972.

2. R. B. Ttaw, R. O. Bonde11d, P. H. Att1X, and C. C. Nogere, U.S. Haval Resenrch Laboratory teport of NRL Progrea, Apr11 1973, PP, 15-31.

3. D. M. ParkIn and A. N. Golend, Brookheven Nattonal Laboratory Report, BNL 50434, Sapterber 1974.

4. X. A. Weaver, J. D. Anderaon, H. H. Berechall, and J. C. Dav1e, Huel. Se1, and Engr. 52, 35 (2973).

5. J. D. Jankina, Nuc2. Sc.1. and Engr. 41, 155 (1970).

4. The totel duace eanes per prteary recoll 10 betwean e faceor of 3 and 5 tives larger thas that for Brich. The 14-ing source velwe to cbout four time lergor ehen the Mincl value, wile values for other eources are lawe by fectore of two or more.

5. It 10 erddeat that by varylas the enetry of the lacldent deutereas, the values of releveat denge parasatere can be verted accordins to the required elevlet10a dewade.

Table III 112untrates in an abolute wones the value of e Li(d,e) source on the buete of displacewant ood cao production ratee. Thare are eow apeclel

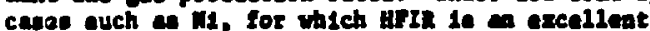
cource becaune the hellue production rate $1 \mathrm{e}$ vary h1gh. Genere115, howver, the $\mathrm{LI}(d, p)$ cource some clowhet to reproductas the olmiteneous diuplecenot raten and gea production rates apacted in the firat rell of a fuldon renctor.

6. D. G. Doran, Huc1. Se1. and Engr, 49, 130 (1972).

7. G. L. Kule1nak1, D. G. Doran, und M. A. Aldou. Froc. of Seventh AST Interational Symponiun on Rffecte of Radiation on Structural Materlale. June 1974 (to be publiohed in ASTY STP eeriea).

B. G. H. Rinchin ead R. S. Peane, Rept. Progrees Phye. 18, 1 (1955).

9. M. I. Robinoon and I. M, Torreas, Phye, Rev. 89. 5008 (1974).

10. A. Aronjoon, Firat-Nall Spectre UaIng ORNL Bencheark Dee1gn, BNR private comunlcation. 